\title{
Crise hídrica e energia: conflitos no uso múltiplo das águas
}

JUCILENE GALVÃO I e CÉLIO BERMANN II

\section{Introdução}

GeSTÃo da água encontra no Brasil um conflito que é histórico e que
envolve a geração de energia elétrica nos reservatórios das usinas hidre-
létricas e os demais usos múltiplos da água.

É interessante salientar que não foi somente a partir da Lei n.9.433 de 8/ janeiro/1997 (Lei das Águas) que instituiu a Política Nacional de Recursos Hídricos no Brasil, que o uso múltiplo em reservatórios foi disciplinado.

$\mathrm{O}$ inciso III do Art. $1^{\circ}$, que enumera os seus cinco fundamentos em que a Lei das Águas se baseia, define que em situações de escassez, o uso prioritário dos recursos hídrico é o consumo humano e a dessedentação de animais.

Em realidade, o uso múltiplo da água já se encontrava presente desde o Decreto n.24.643 de 10/julho/1934, também denominado "Código das Águas".

No Art. 143, do Livro III - Forças Hidráulicas - Regulamentação da Indústria Hidroelétrica, em seu Título I - Capítulo I - Energia Hidráulica e seu Aproveitamento, se encontra assim definido o uso múltiplo:

Art. 143. Em todos os aproveitamentos de energia hidráulica serão satisfeitas exigências acauteladoras dos interesses gerais:

a) da alimentação e das necessidades das populações ribeirinhas;

b) da salubridade pública;

c) da navegação;

d) da irrigação;

e) da proteção contra as inundações;

f) da conservação e livre circulação do peixe;

g) do escoamento e rejeição das águas.

Segundo o Código das Águas, a propriedade dos rios deixava de ser do proprietário da terra onde corriam, e passava, conforme o caso, a ser propriedade do município, do estado ou da União. Por outro lado, o Código estabelecia uma série de regras e restrições ao uso das águas, determinando que o uso para abastecimento humano era o mais importante.

Ainda segundo o Código das Águas, a propriedade das quedas d'água e do potencial hidrelétrico deixava de ser do proprietário da terra e passava a ser patrimônio da nação, sob a forma de propriedade da União. A partir de então, 
o aproveitamento de potencial hidrelétrico passou a depender de autorização ou concessão (por prazo máximo de trinta ou cinquenta anos, conforme o montante dos investimentos).

No período anterior ao Código das Águas, o Estado não intervinha na produção e distribuição de energia, apenas conferia autorizações para o funcionamento das companhias. Não havia qualquer legislação sobre a energia elétrica e sobre recursos hídricos. Os estados e municípios gozavam de grande autonomia para estabelecer contratos e autorizações para as empresas privadas de energia.

As companhias que na época detinham o monopólio da geração e distribuição de energia elétrica - a empresa canadense Light e a norte-americana Amforp - tinham direito de corrigir suas tarifas e de receber o equivalente em ouro (a chamada "cláusula-ouro"), de maneira a ficarem protegidas da inflação e da desvalorização da moeda brasileira - naquela época a unidade monetária era o mil réis.

Com o Código das Águas, as tarifas passaram a ser fixadas segundo os custos de operação e o valor histórico dos investimentos, o que significava o fim da "cláusula-ouro" e da correção monetária automática conforme a variação cambial.

O Sistema Elétrico Brasileiro que se constituiu a partir do Código das Águas de 1934 acabou por transformar as empresas concessionárias, que obtinham a outorga de seus reservatórios para a finalidade de geração de energia hidrelétrica, em verdadeiras proprietárias dos rios e de seus cursos d'água.

As empresas públicas de geração, federais e estaduais, se formaram notadamente a partir dos anos 1940, processo esse que foi impulsionado pela institucionalização da Taxa de Eletrificação, a título de capitalização para viabilização dos programas de eletrificação em cada um dos estados.

A prioridade da água para geração de eletricidade assim se estabeleceu e só passou a ser questionada a partir da Lei das Águas de 1997. Conforme a Lei, a água deve ser utilizada de forma a garantir ao mesmo tempo o abastecimento residencial e industrial, a energia e a irrigação, entre outros usos. $\mathrm{O}$ consumo humano e de animais, no entanto, é prioritário em situações de estiagem.

$\mathrm{Na}$ época em que o sistema elétrico brasileiro foi implantado, as exigências ambientais não eram tão rigorosas e o uso múltiplo das águas não era a prioridade dos projetos. Segundo o diretor-presidente da ANA (Agência Nacional de Águas), Vicente Andreu Guillo, "há uma preponderância natural histórica do uso energético, sem levar em consideração as atividades que foram incorporadas ao reservatório":

Muitas vezes há uma ausência de regras claras, porque confrontamos o novo e o antigo praticamente ao mesmo tempo. O antigo é a instalação do sistema elétrico brasileiro. [...] E com o passar dos anos, foram sendo constituídas novas atividades econômicas, que não foram incorporadas no funcionamento do sistema elétrico brasileiro, compatíveis com o uso múltiplo das águas. (Agência Pública, 2015) 
A crise hídrica recente, e que ainda está sendo vivenciada no país, evidenciou os conflitos entre a geração de energia e o uso múltiplo das águas. Identificar esses conflitos e fazer uma reflexão sobre seus fundamentos são os objetivos do texto que se segue.

\section{A crise hídrica e a geração de energia elétrica}

No presente estudo, foram considerados os dados relativos à evolução do volume útil dos principais reservatórios das usinas hidrelétricas localizadas na região Sudeste do país.

O conceito de "Volume Útil" em reservatórios diz respeito ao volume compreendido entre os níveis mínimo operacional e máximo operacional, efetivamente destinado à operação do reservatório, ou seja, ao atendimento das demandas de água. Deve considerar as perdas por evaporação e por infiltração no solo, quando estas forem significativas.

Segundo Lopes e Santos $(2002$, p.6), o volume útil de um reservatório de uma usina hidrelétrica pode ser entendido como o volume de armazenamento necessário para garantir uma vazão regularizada constante durante o período mais crítico de estiagem observado.

Isso significa que o volume útil pode atingir $0,00 \%$ mas isso não significa que a usina hidrelétrica fique impossibilitada de gerar eletricidade. Geralmente, a tomada d'água, onde está posicionado o canal de adução de uma usina, se localiza alguns metros abaixo do mínimo operacional definido para regularização das vazões, conforme pode ser visualizado na Figura 1. Abaixo desse nível, a água continua sendo utilizada até atingir o canal de adução, quando a geração se interrompe, sob o risco de afetar os equipamentos eletromecânicos da usina - turbinas e geradores.

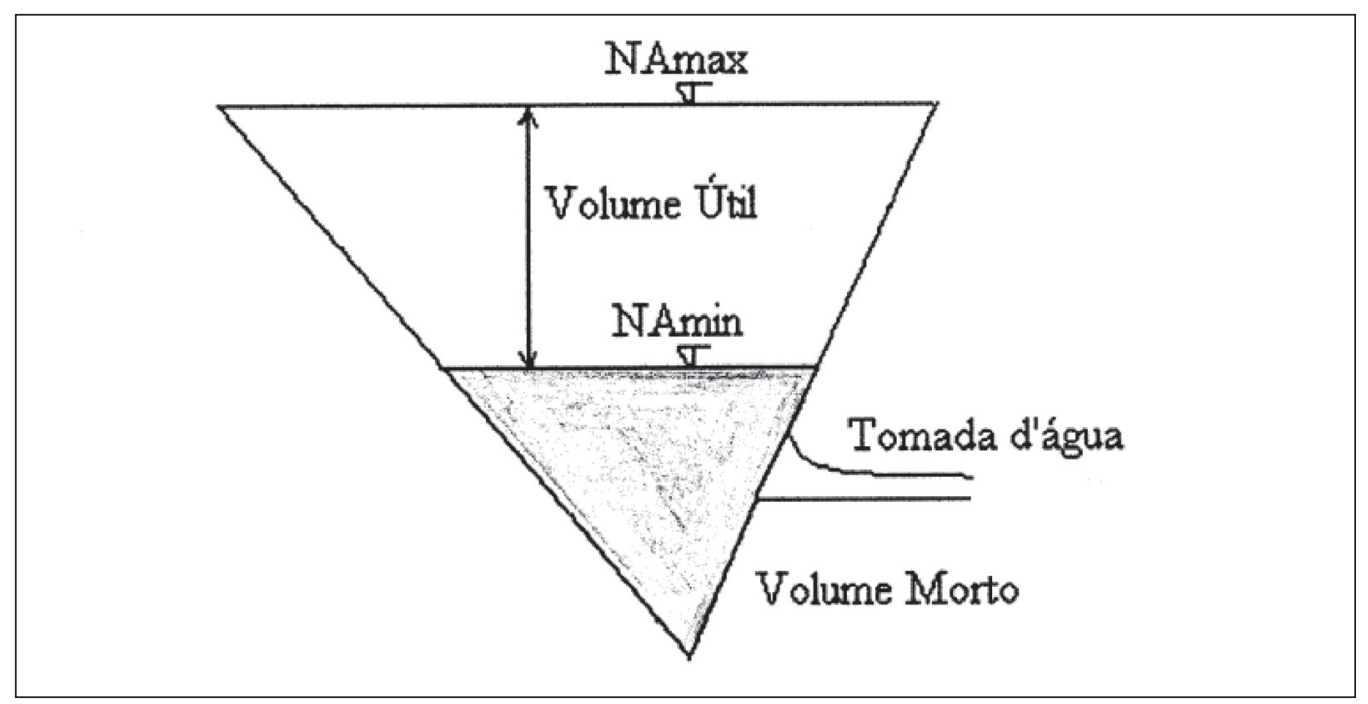

Fonte: Lopes e Santos (2002).

Figura l - Volume útil do reservatório de uma usina hidrelétrica. 
Em tal situação o conflito com os usos múltiplos se agudiza, pois a operação do reservatório, cuja prioridade é a geração de energia elétrica, acaba por trazer dificuldades, senão impedir, a utilização das águas para navegação, irrigação, pesca e lazer, entre outros.

A Figura 2 identifica a região de estudo do presente trabalho, com a localização das principais Usinas Hidrelétricas na região $\mathrm{SE} / \mathrm{CO}$, com destaque aos reservatórios das UHEs Ilha Solteira (rio Paraná, 3.444 MW) com outorga de concessão à empresa Cesp; Três Irmãos (rio Tietê, 807,5 MW), com outorga de concessão, a partir de março/2014, ao consórcio Novo Oriente, formado pela Fip Constantinopla, com 50,1\% de participação, e Furnas, com 49,9\%; Água Vermelha (rio Grande, 1.396,2 MW) com outorga de concessão à empresa AES-Tietê; Furnas (rio Grande, 1.216 MW), com outorga de concessão à empresa Furnas; Marimbondo (rio Grande, 1.440 MW); Capivara (rio Paranapanema, $640 \mathrm{MW}$ ), com outorga de concessão à empresa Duke Energy.

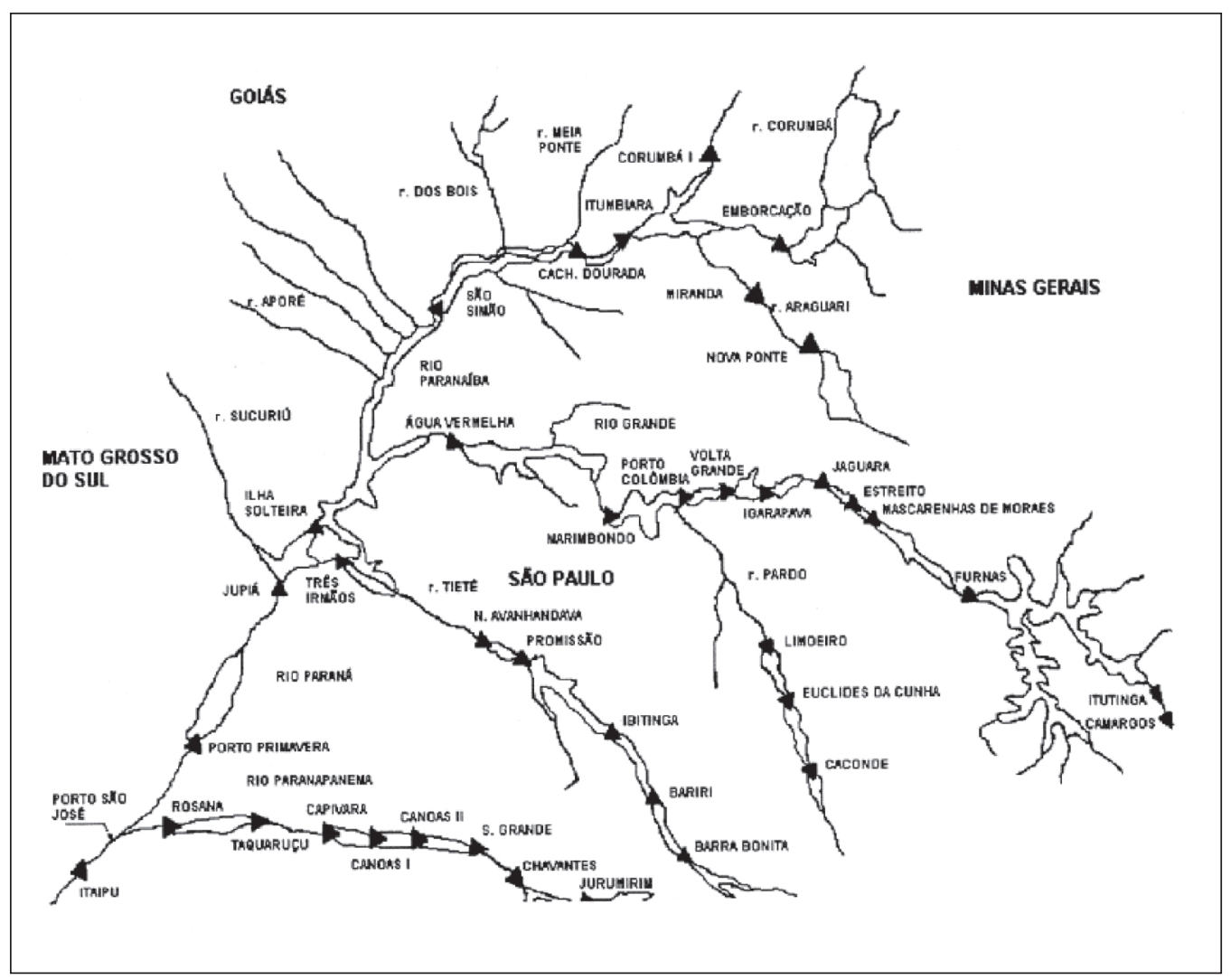

Figura 2 - Mapa com a localização das principais Usinas Hidrelétricas na região SE/CO.

Os dados referentes ao comportamento de cada um dos seis reservatórios no período 2013-2014, considerados neste estudo, foram obtidos a partir do ONS-Operador Nacional do Sistema Elétrico, que disponibiliza no seu sítio na web o "Volume Útil dos Principais Reservatórios". ${ }^{1}$ 
Esse conjunto de usinas, com capacidade instalada total de 8.943,7 MW, representava em dezembro de 2014 cerca de $10 \%$ do total da capacidade instalada hidrelétrica, de 89.193 MW, conforme o Boletim Mensal de Monitoramento do Sistema Elétrico Brasileiro (MME/SSE, dezembro de 2014).

Esses números conferem representatividade ao comportamento de cada um dos reservatórios no contexto do Sistema Elétrico Brasileiro no período 2013-2014, considerado na presente avaliação.

A situação mais crítica, reveladora da Crise Hídrica, é constatada no comportamento dos reservatórios das usinas Ilha Solteira e Três Irmãos, conforme respectivamente apresentado nas Tabelas 1 e 2 e Figuras 3 e 4.

Tabela l - Evolução do volume útil do reservatório da UHE Ilha Solteira 2013$2014(\mathrm{em} \%)$

\begin{tabular}{c|c|c|c}
\hline Mês/Ano & 2013 & 2014 & Acréscimo/Redução \\
\hline Jan & 57,94 & 45,03 & $-22,28 \%$ \\
\hline Fev & 55,71 & 38,87 & $-30,23 \%$ \\
\hline Mar & 79,49 & 42,64 & $-46,36 \%$ \\
\hline Abr & 87,54 & 31,02 & $-64,56 \%$ \\
\hline Mai & 69,67 & 4,56 & $-93,45 \%$ \\
\hline Jun & 86,05 & 0,00 & $-100,00 \%$ \\
\hline Jul & 84,78 & 0,00 & $-100,00 \%$ \\
\hline Ago & 78,23 & 0,00 & $-100,00 \%$ \\
\hline Set & 57,13 & 0,00 & $-100,00 \%$ \\
\hline Out & 59,78 & 0,00 & $-100,00 \%$ \\
\hline Nov & 61,21 & 0,00 & $-100,00 \%$ \\
\hline Dez & 57,33 & 0,00 & \\
\hline
\end{tabular}

Fonte: ONS, Volume útil dos principais reservatórios, 2015. 


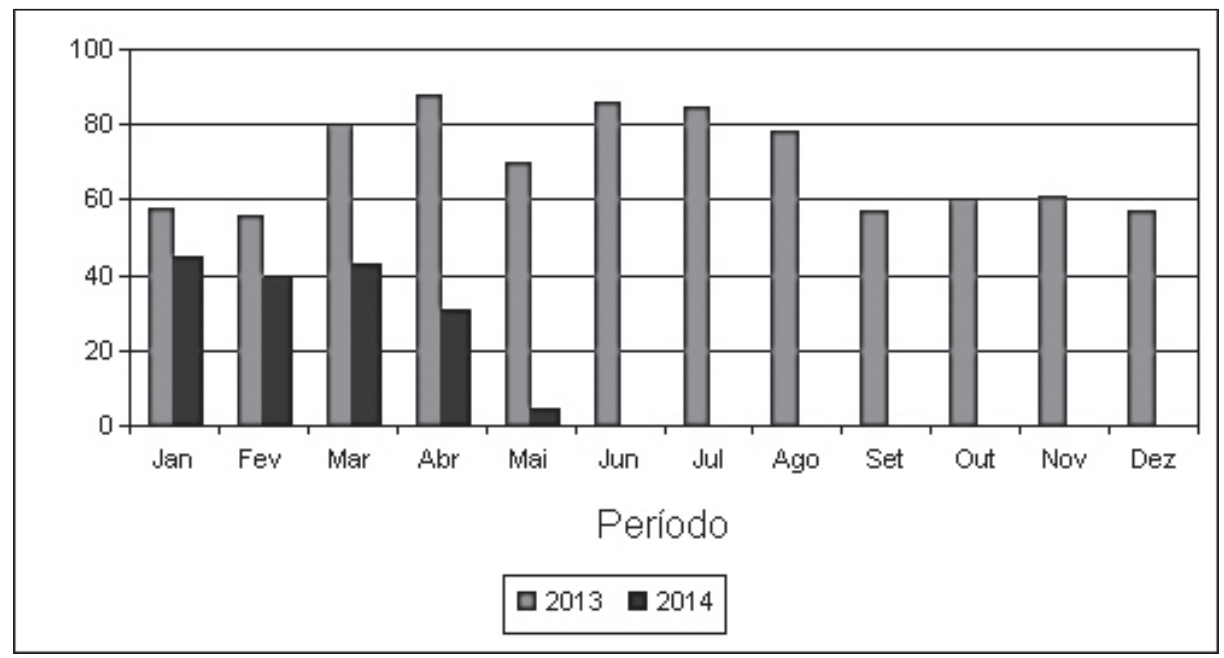

Fonte: ONS, Volume útil dos principais reservatórios, 2015.

Figura 3 - Evolução do volume útil do reservatório da UHE Ilha Solteira.

Tabela 2 - Evolução do volume útil do reservatório da UHE Três Irmãos 2013$2014(\mathrm{em} \%)$

\begin{tabular}{c|c|c|c}
\hline Mês/Ano & 2013 & 2014 & Acréscimo/Redução \\
\hline Jan & 56,63 & 46,75 & $-17,45 \%$ \\
\hline Fev & 57,04 & 38,81 & $-31,96 \%$ \\
\hline Mar & 81,20 & 43,56 & $-46,35 \%$ \\
\hline Abr & 89,34 & 33,92 & $-62,03 \%$ \\
\hline Mai & 82,27 & 15,03 & $-81,73 \%$ \\
\hline Jun & 90,20 & 0,00 & $-100,00 \%$ \\
\hline Jul & 87,19 & 0,00 & $-100,00 \%$ \\
\hline Ago & 80,78 & 0,00 & $-100,00 \%$ \\
\hline Set & 60,93 & 0,00 & $-100,00 \%$ \\
\hline Out & 62,98 & 0,00 & $-100,00 \%$ \\
\hline Nov & 60,31 & 0,00 & $-100,00 \%$ \\
\hline Dez & 58,27 & 0,00 & \\
\hline
\end{tabular}

Fonte: ONS, Volume útil dos principais reservatórios, 2015. 


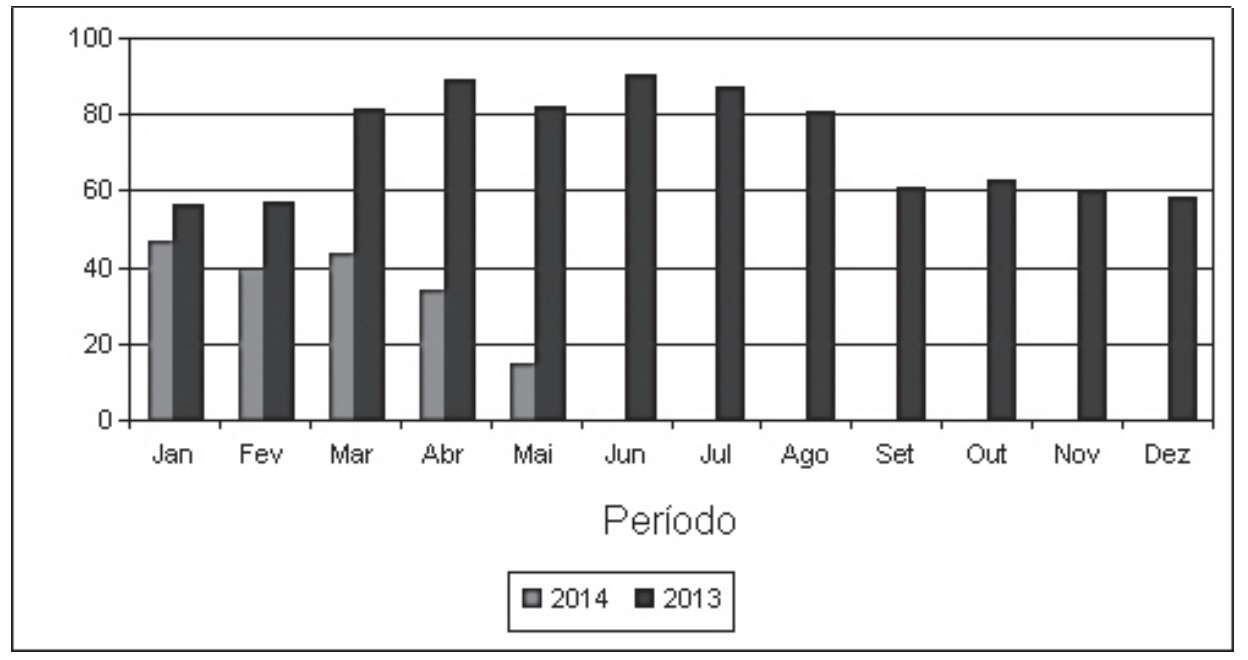

Fonte: ONS, Volume útil dos principais reservatórios, 2015.

Figura 4 - Evolução do volume útil do reservatório da UHE Três Irmãos.

Observam-se nos dois reservatórios acentuadas reduções nos respectivos volumes úteis, comparando os dados de 2014 em relação a 2013. Em particular, a partir do mês de junho de 2014, ambos os reservatórios apresentaram $0,00 \%$ nos respectivos volumes úteis, trazendo graves problemas para a geração de energia elétrica no país.

\section{Geração de energia versus usos múltiplos no reservatório da UHE Ilha Solteira}

O conflito geração de eletricidade versus usos múltiplos se ampliou na operação da UHE Ilha Solteira em razão da crise hídrica. A redução do nível de água prejudicou também as outras atividades econômicas: o turismo nas praias artificiais em torno do lago, a piscicultura baseada na criação de tilápias em tanques-rede por cerca de quarenta produtores (pequenos, médios e grandes) e a pesca artesanal, além de faltar água para a irrigação de plantações, conforme relata a matéria da Agência Pública "Ilha Solteira pede água", publicada em março de 2015.

Conforme a matéria, segundo a Secretaria Municipal de Turismo do município de Ilha Solteira, houve uma redução de $70 \%$ do público esperado para o verão. Com a estiagem, a água recuou 100 metros e a cidade perdeu sua principal atração: as praias artificiais com seus quiosques e atividades aquáticas.

"O turismo está parado, você não vê um jet-ski andando, um barco andando, as marinas todas paradas, então o prejuízo para a região, cuja base da economia é o reservatório, torna-se incalculável. As lojas de pesca, manutenção para jet-ski e ranchos já estão sentindo", apontava o biólogo e piscicultor Emerson Esteves, que reside à margem do reservatório de Ilha Solteira, na cidade de Rubineia. 
Ainda conforme a matéria, o prejuízo foi maior ainda para os empresários que, como ele, utilizam o reservatório da usina para a criação de tilápias em tanques-rede. Com o lago abaixo de seu nível habitual, os tanques foram constantemente deslocados e em alguns pontos a produção ficou comprometida.

"O setor aquícola emprega três mil pessoas diretamente e caiu $30 \% \mathrm{em}$ 2014. Já tivemos desemprego, queda na produção, queremos nossos direitos e assegurar uma cota mínima para o reservatório", explica Emerson Esteves, proprietário da piscicultura Peixe Vivo.

A estiagem de Ilha Solteira acabou se tornando centro de uma batalha judicial entre piscicultores, a Cesp e o Operador Nacional do Sistema. Conforme a matéria, o funcionamento da usina abaixo da cota de 323 metros prejudicava a produção de peixes porque enquanto a vazão do rio na barragem continuava alta, para garantir a geração de energia, a montante (acima da usina) ficava vazia, impedindo a criação dos peixes nos tanques. Por isso, o processo dos criadores acusava Cesp e ONS de má gestão da água.

O juiz Rafael Andrade de Margalho, da $1^{\text {a }}$ Vara Federal de Jales, no interior de São Paulo, deferiu liminar exigindo da Cesp o fechamento da usina até que se reestabelecesse a cota mínima para operação. Caso descumprisse a liminar, a companhia deveria arcar com uma multa de R\$ 100 mil por dia de operação. Segundo Margalho:

Os piscicultores têm uma concessão para explorar a margem da represa com gaiolas de peixe e estavam tendo um prejuízo muito sério com essas gaiolas, que precisavam ser deslocadas muito para o meio. A água baixou mais de 300 metros de onde era a antiga margem, você já consegue ver as cidades que foram inundadas. Além disso, havia prejuízo de turismo na região e a usina estava funcionando abaixo do nível legal. (Agência Pública, março de 2015)

Em nenhum momento, entretanto, a decisão judicial foi cumprida. "Nós ganhamos, mas em nenhum momento a CESP e o ONS cumpriram a decisão", conforme afirmou na matéria o empresário Emerson Esteves.

A liminar favorável aos piscicultores foi derrubada no Tribunal Federal, sob alegação do ONS de que "a manutenção da liminar poderia causar um apagão no País”, explicou o juiz Margalho. Segundo ele, o Operador Nacional do Sistema alegou que "o impacto de interromper a energia seria nacional, enquanto o impacto ambiental seria apenas local. Não se discutia ali que exista dano ambiental, ele existe, mas seria mais importante a manutenção da energia".

Para o ex-ministro da Pesca e Aquicultura no segundo mandato do governo Lula (2006-2011), Altemir Gregolin “os órgãos que trabalham no sistema elétrico devem rever os critérios; aquilo que era atividade complementar (piscicultura) passou a ser importante para a região. O ONS, a ANA, a Aneel e o Ministério da Pesca precisam rever os usos múltiplos da água e a piscicultura".

Depois de a liminar ser derrubada, abriu-se uma ação civil pública (em defesa de interesses coletivos) encabeçada pelo Ministério Público de Jales. Na opi- 
nião do procurador José Rubens Plates, responsável pelo processo, a decisão do Operador Nacional do Sistema viola a legislação vigente sobre o uso das águas:

Do nosso ponto de vista e também do juiz federal que decidiu a liminar, isso contraria a legislação, que fala que em época de seca, de escassez de água, deve-se priorizar o consumo humano e a dessedentação animal, em detrimento de outros usos de água. Do nosso ponto de vista, a Cesp e o ONS estariam priorizando somente a produção de energia. Então é uma ponderação de interesse, uma ponderação de valores utilizados nesse caso.

Em nota, a ONS afirmou que o "gerenciamento para flexibilizar as restrições de uso múltiplo da água estocada nos reservatórios em decorrência da escassez de recursos hidroenergéticos tem sido realizado com a participação da ANA, do Ministério do Meio Ambiente, da Aneel, do Ministério de Minas e Energia e dos agentes proprietários das instalações envolvidas". O Operador Nacional do Sistema declarou ainda que "face à escassez de recursos hídricos, tem sido necessário flexibilizar as restrições de uso múltiplo".

Vale lembrar que a concessão da Cesp para administrar a Usina de Ilha Solteira se encerra em julho de 2015. O presidente da ANA, Vicente Andreu, anunciou que a agência apoiará mudanças nas regras de concessão de operação das usinas e a recuperação do reservatório. "As usinas, quando vencerem a concessão, precisarão de uma nova outorga que incorpore os usos que a água passou a adquirir ao longo dos anos."

Tal declaração confirma a questão que é debatida no presente estudo: a prioridade para a geração de energia elétrica e a ausência de mecanismos que assegurem o uso múltiplo das águas nas outorgas por meio das quais são elaborados os atuais contratos de concessão das usinas hidrelétricas.

\section{Reservatórios da usinas hidrelétricas no rio Grande}

A mesma situação verificada nos reservatórios das UHE Ilha Solteira e Três Irmãos pode ser observada nos reservatórios das usinas hidrelétricas localizados no rio Grande $(\mathrm{SP} / \mathrm{MG})$, embora nenhum desses tenha chegado à redução de $100,00 \%$.

O comportamento do reservatório da UHE Água Vermelha pode ser observado na Tabela 3 e na Figura 5.

Por sua vez, o comportamento do reservatório da UHE Furnas pode ser observado na Tabela 4 e na Figura 6.

Em todos os três reservatórios observa-se o mesmo vigor na redução dos respectivos volumes úteis em razão da crise hídrica, em épocas diferentes devido ao regime de operação na geração de energia de cada uma das usinas.

Para a UHE Água Vermelha, as maiores reduções nos volumes úteis se verificaram nos meses de abril $(-82,41 \%)$ e junho $(-82,69 \%)$, enquanto para a UHE Furnas, as maiores reduções se verificaram nos meses de outubro $(-73,59 \%)$ e novembro $(-73,53 \%)$. Por seu turno, a UHE Marimbondo teve as maiores reduções nos meses de julho $(-80,99 \%)$ e agosto $(-82,41)$. 
Tabela 3 - Evolução do volume útil do reservatório da UHE Água Vermelha 2013-2014 (em \%)

\begin{tabular}{c|c|c|c}
\hline Mês/Ano & 2013 & 2014 & Acréscimo/Redução \\
\hline Jan & 28,93 & 37,89 & $+30,97 \%$ \\
\hline Fev & 40,33 & 27,29 & $-32,33 \%$ \\
\hline Mar & 61,53 & 30,12 & $-51,05 \%$ \\
\hline Abr & 80,37 & 14,14 & $-82,41 \%$ \\
\hline Mai & 93,81 & 22,91 & $-75,58 \%$ \\
\hline Jun & 91,24 & 15,79 & $-82,69 \%$ \\
\hline Jul & 83,67 & 18,49 & $-77,90 \%$ \\
\hline Ago & 69,09 & 15,04 & $-66,13 \%$ \\
\hline Set & 66,84 & 22,64 & $-71,81 \%$ \\
\hline Out & 58,70 & 16,55 & $-71,42 \%$ \\
\hline Nov & 56,12 & 16,04 & $-42,25 \%$ \\
\hline Dez & 41,51 & 23,97 & \\
\hline
\end{tabular}

Fonte: ONS, Volume útil dos principais reservatórios, 2015.

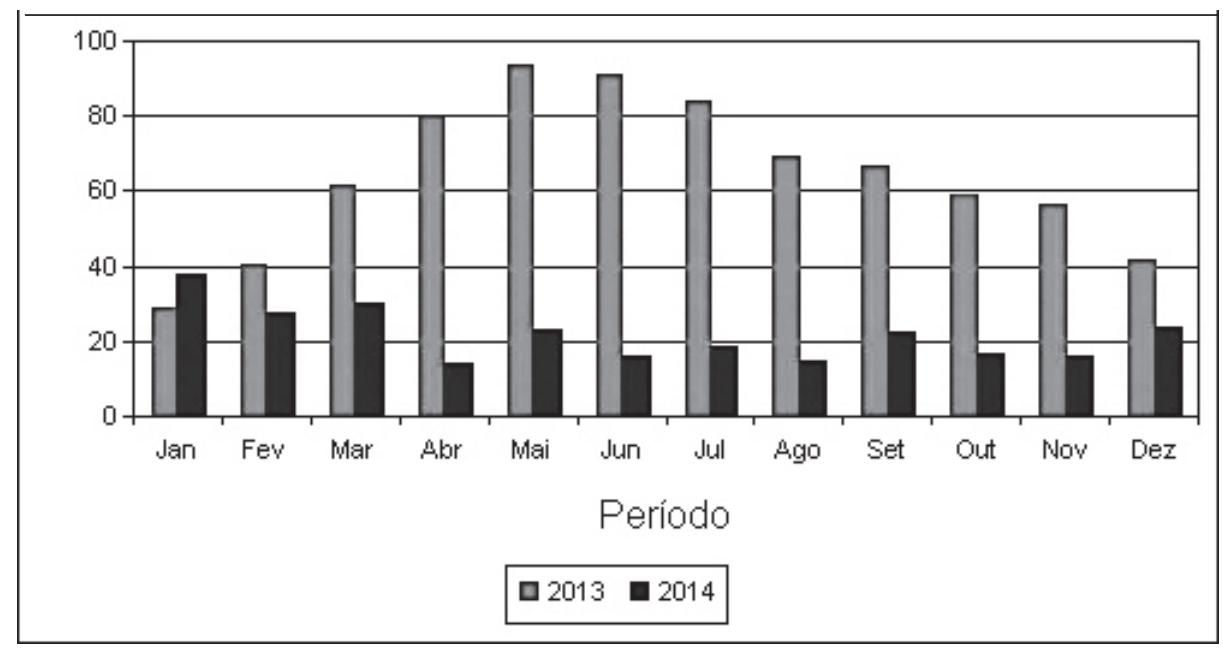

Fonte: ONS, Volume útil dos principais reservatórios, 2015.

Figura 5 - Evolução do volume útil do reservatório da UHE Água Vermelha. 
Tabela 4 - Evolução do volume útil do reservatório da UHE Furnas

\begin{tabular}{c|c|c|c}
\hline \multicolumn{2}{c|}{$2013-2014(\mathrm{em} \%)$} & 2014 & Acréscimo/Redução \\
\hline Mês/Ano & 2013 & 46,26 & $+43,44 \%$ \\
\hline Jan & 32,25 & 34,14 & $-32,07 \%$ \\
\hline Fev & 50,26 & 27,27 & $-56,42 \%$ \\
\hline Mar & 62,58 & 29,11 & $-59,29 \%$ \\
\hline Abr & 71,51 & 29,37 & $-58,47 \%$ \\
\hline Mai & 70,72 & 29,11 & $-59,17 \%$ \\
\hline Jun & 71,29 & 28,61 & $-57,70 \%$ \\
\hline Jul & 67,64 & 27,55 & $-54,55 \%$ \\
\hline Ago & 60,61 & 22,00 & $-59,02 \%$ \\
\hline Set & 53,69 & 13,29 & $-73,59 \%$ \\
\hline Out & 50,32 & 11,64 & $-75,53 \%$ \\
\hline Nov & 47,56 & 13,41 & $-73,12 \%$ \\
\hline Dez & 49,89 & 2015 &
\end{tabular}

Fonte: ONS, Volume útil dos principais reservatórios, 2015.

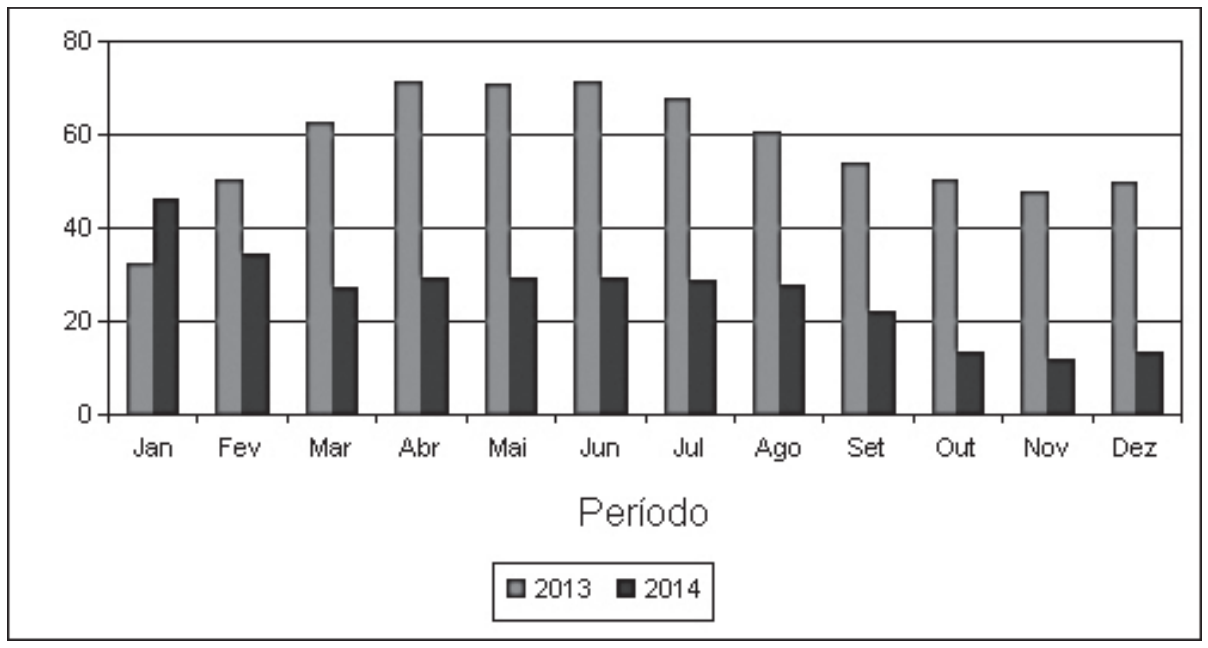

Fonte: ONS, Volume útil dos principais reservatórios, 2015.

Figura 6 - Evolução do Volume Útil do Reservatório da UHE Furnas. 
Ainda, o comportamento do reservatório da UHE Marimbondo pode ser observado na Tabela 5 e Figura 7.

Tabela 5 - Evolução do Volume Útil do Reservatório da UHE Marimbondo 2013-2014 (em \%)

\begin{tabular}{c|c|c|c}
\hline Mês/Ano & 2013 & 2014 & Acréscimo/Redução \\
\hline Jan & 27,32 & 28,59 & $+4,65 \%$ \\
\hline Fev & 43,15 & 19,16 & $-55,60 \%$ \\
\hline Mar & 57,83 & 25,14 & $-56,53 \%$ \\
\hline Abr & 82,21 & 26,36 & $-67,94 \%$ \\
\hline Mai & 89,74 & 20,13 & $-77,57 \%$ \\
\hline Jun & 86,84 & 20,46 & $-76,44 \%$ \\
\hline Jul & 77,45 & 14,72 & $-80,99 \%$ \\
\hline Ago & 66,70 & 11,73 & $-71,45 \%$ \\
\hline Set & 54,71 & 15,62 & $-78,88 \%$ \\
\hline Out & 55,07 & 11,63 & $-73,05 \%$ \\
\hline Nov & 41,48 & 11,18 & $-55,89 \%$ \\
\hline Dez & 38,86 & 17,14 & \\
\hline
\end{tabular}

Fonte: ONS, Volume útil dos principais reservatórios, 2015.

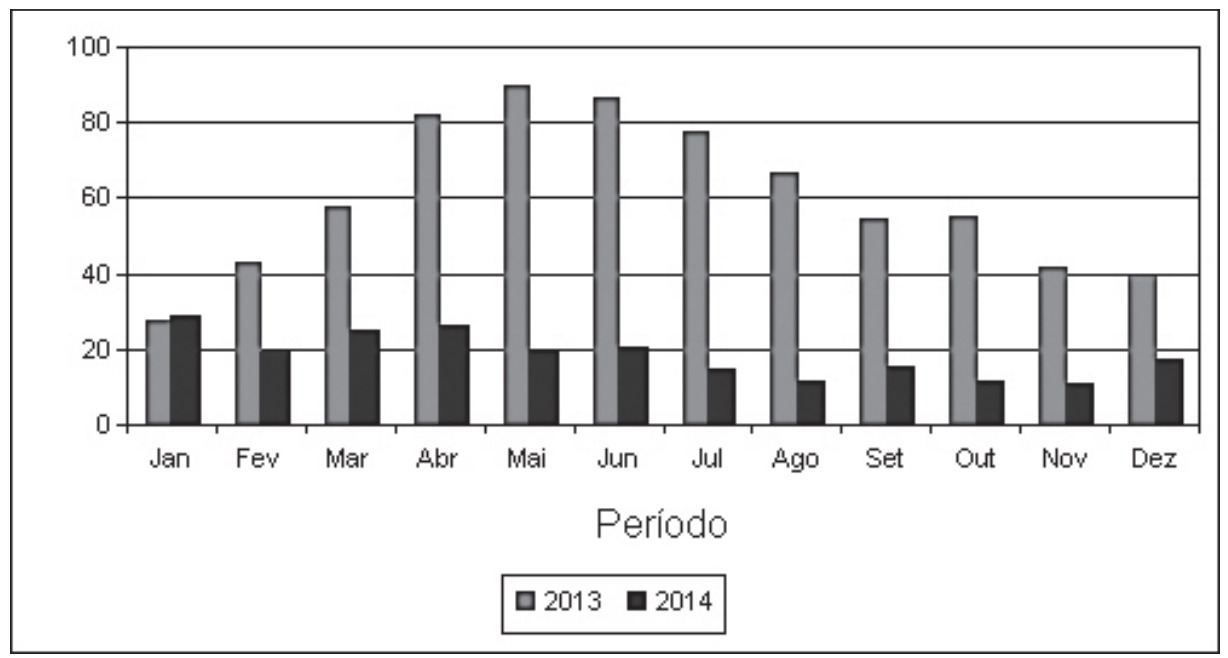

Fonte: ONS, Volume útil dos principais reservatórios, 2015.

Figura 7 - Evolução do volume útil do reservatório da UHE Marimbondo. 
Os menores volumes úteis verificados em 2014 foram de 15,04\% (agosto) na UHE Água Vermelha, 11,64\% (novembro) na UHE Furnas, e 11,18\% (novembro) na UHE Marimbondo.

Esses dados evidenciam o rigor da redução dos volumes úteis nos três reservatórios localizados no rio Grande, na comparação dos valores no ano de 2014 em relação a 2013, trazendo também graves problemas para a geração de energia elétrica no país.

\section{Reservatórios da usinas hidrelétricas no rio Paranapanema}

O mesmo comportamento relativo à redução do volume útil da usina hidrelétrica Capivara, no rio Paranapanema (SP/PR), pode ser observado, conforme a Tabela 6 e respectiva Figura 8.

Tabela 6 - Evolução do volume útil do reservatório da UHE Capivara 2013-2014 (em \%)

\begin{tabular}{c|c|c|c}
\hline Mês/Ano & 2013 & 2014 & Acréscimo/Redução \\
\hline Jan & 34,88 & 65,17 & $+86,84 \%$ \\
\hline Fev & 57,93 & 37,30 & $-35,61 \%$ \\
\hline Mar & 87,20 & 31,21 & $-64,21 \%$ \\
\hline Abr & 100,70 & 29,87 & $-70,34 \%$ \\
\hline Mai & 98,80 & 30,22 & $-69,41 \%$ \\
\hline Jun & 99,00 & 68,37 & $-30,94 \%$ \\
\hline Jul & 98,90 & 79,45 & $-32,97 \%$ \\
\hline Ago & 99,40 & 66,63 & $-32,62 \%$ \\
\hline Set & 96,21 & 64,83 & $-47,05 \%$ \\
\hline Out & 99,10 & 52,47 & $-79,91 \%$ \\
\hline Nov & 97,11 & 19,51 & $-71,16 \%$ \\
\hline Dez & 80,37 & 23,18 & \\
\hline
\end{tabular}

Fonte: ONS, Volume útil dos principais reservatórios, 2015. 


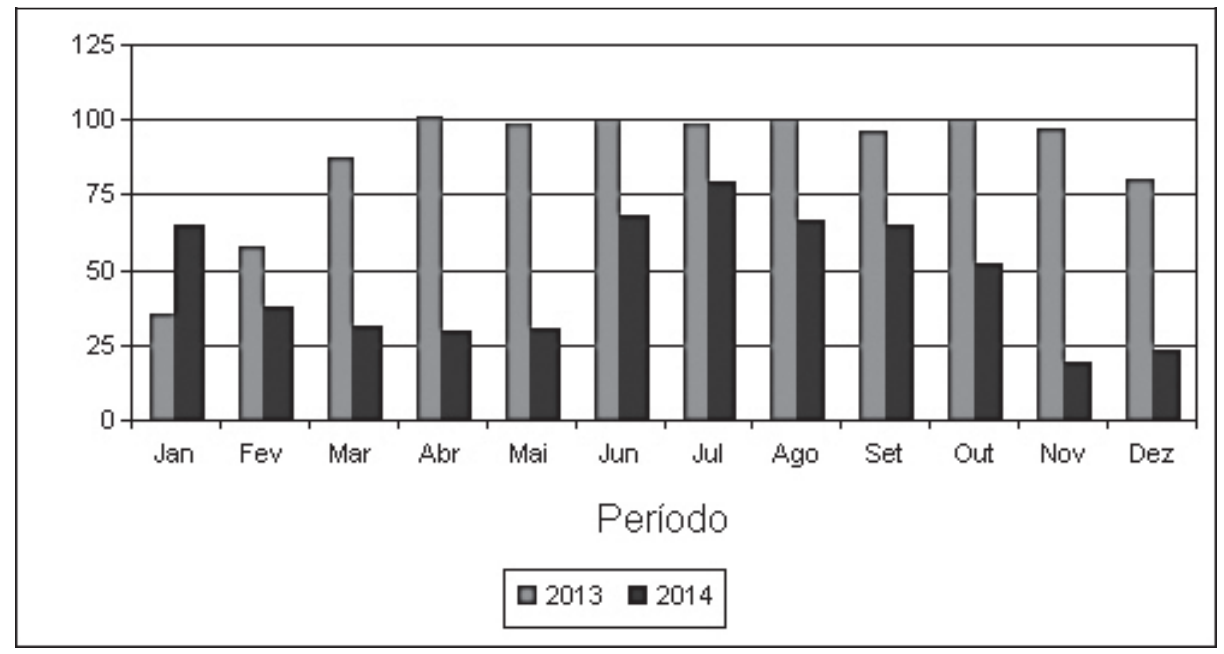

Fonte: ONS, Volume útil dos principais reservatórios, 2015.

Figura 8 - Evolução do volume útil do reservatório da UHE Capivara.

Com referência à UHE Capivara, as maiores reduções se verificaram nos meses de novembro $(-79,91 \%)$ e dezembro $(-71,16 \%)$, tendo sido também importante a redução ocorrida em abril $(-70,34 \%)$.

O menor volume útil verificado em 2014 foi de 19,51\% (novembro) na UHE Capivara, evidenciando que o mês de novembro foi aquele em que a crise hídrica no período 2013-2014 foi mais sentida no Sistema Elétrico Brasileiro.

A similaridade nos comportamentos dos reservatórios das usinas hidrelétricas analisadas neste estudo, definidas pelo regime hidrológico verificado no período na região Sudeste, salvo as variações no regime de operação de cada usina, indica que a crise hídrica afetou com maior intensidade a disponibilidade de energia para atender a carga demandada no Sistema Elétrico Brasileiro em determinados períodos, o que exigiu que outras fontes de energia fossem buscadas, com o objetivo de proporcionar segurança na oferta de eletricidade no país.

\section{Da crise hídrica no Sistema Elétrico Brasileiro à crise econômico-financeira}

Para o Sistema Elétrico Brasileiro, extremamente dependente da geração hidrelétrica $(67,4 \%$, cf. MME/SEE, dezembro de 2014), a redução dos níveis de precipitação ocorrida no período, com a consequente redução das afluências naturais nos reservatórios, acarretaram a necessidade de recorrer à geração termelétrica.

Essa situação levou a uma crise na segurança energética do país, trazendo incertezas para as atividades econômicas - indústria, comércio e serviços - e para a população.

Para garanti-la, o governo acabou optando pela compra de energia através das usinas termoelétricas, cujo custo de geração é maior. Essa situação acabou 
gerando um espaço de manipulação em que os valores das tarifas subiram a preços absolutamente exorbitantes, fruto da especulação que começou a se fazer, pois o custo da energia elétrica para o consumidor final está sujeita à manipulação dos vários atores que intermedeiam a comercialização da energia atualmente no país.

A energia que poderia ser vendida e repassada a um valor da ordem média de 120 reais por megawatts/hora (valores praticados em razão dos custos da geração hidrelétrica), chegou em julho/agosto de 2014 a valores superiores a 500 reais por megawatts/hora. Como não havia energia suficiente para garantir os contratos de disponibilidade de energia para todos os seus consumidores, as distribuidoras tiveram de comprar energia a esse preço. Como essas empresas não podem ou não puderam repassar esse aumento para as tarifas, pois participam do assim denominado mercado regulado de energia, fiscalizado e administrado pela Aneel que concede apenas reajustes tarifários anuais, recorreram ainda em abril de 2014 ao governo, para que ele levantasse recursos necessários a fim de cobrir os gastos incorridos com a compra dessa energia para suprir a demanda que já estava contratada.

O governo conseguiu, em abril de 2014, articular com vários bancos privados, com a participação da Caixa Econômica Federal e do Banco do Brasil, um montante de 11,2 bilhões de reais a título de empréstimo para que as distribuidoras honrassem com os compromissos que elas tiveram na compra da energia mais cara.

O prazo do pagamento para honrar o compromisso na aquisição de energia em junho venceu em agosto de 2014. Novamente as distribuidoras alegaram impossibilidade de fazer o pagamento. Mais uma vez, o governo articulou um segundo empréstimo no valor de 6,5 bilhões de reais, dessa vez sem a participação de bancos privados.

Como resultado desse processo, o débito no valor de R\$ 17,7 bilhões foi repassado nas tarifas de todos os consumidores de energia elétrica - residencial, as indústrias, o comércio - a partir de 2015.

Verifica-se que a crise hídrica levou a uma crise econômico-financeira das empresas concessionárias da distribuição de eletricidade no país, tendo o governo demonstrado uma incapacidade de gerenciar a crise, devido a uma série de erros anteriores na condução da política energética. ${ }^{2}$

\section{A crise hídrica e o conflito Água/Energia no rio Paraíba do Sul}

A diminuição do volume de precipitações e as mudanças apresentadas no padrão climático do Sudeste do país a partir de 2012 já indicavam que o abastecimento de água e atividades correlatas poderiam ficar comprometidos nos anos seguintes. Em realidade, diversos estudos sobre a disponibilidade hídrica na Região Metropolitana de São Paulo e projetos que buscavam opções para o abastecimento indicavam que tais problemas já eram previstos desde o início dos anos 2000 . 
Conforme o Documento “Conjuntura dos Recursos Hídricos no Brasil Informe 2014", divulgado pela ANA em 20.3.2015:

No sudeste do Brasil as chuvas de 2014 foram especialmente anômalas. Levando em consideração apenas estações com mais de 50 anos de dados, verificou-se que em $25 \%$ a chuva desse ano ficou entre as 3 piores já registradas. No estado de São Paulo o número sobe para 50\%, sendo que em 30\% o evento foi o mais seco já registrado.

As bacias de contribuição dos principais reservatórios de abastecimento urbano da região Sudeste como é o caso do Sistema Cantareira e os sistemas do Paraíba do Sul contaram em 2014 com precipitações próximas as mais baixas já registradas no histórico, o que impediu a recuperação dos níveis dos reservatórios. Da análise do grau de excepcionalidade deste evento de seca na região, a partir de tempo de retorno, nota-se que grande parte das estações registrou seca com período de retorno superior a 100 anos, o que permite rotular este evento como raro. (ANA, 2015b, p.11)

Além das questões climáticas, podem-se considerar, ainda, outros fatores contribuintes para a diminuição na disponibilidade dos recursos hídricos, como ampliação na necessidade de abastecimento devido ao aumento populacional, consequente aumento na ocupação do solo, responsável pela mudança nos níveis de infiltração e escoamento de águas, aumento nas atividades produtivas e consequente aumento na poluição das águas, entre outros fatores.

Apesar, no entanto, do cenário que se desenhava, os gestores públicos e privados do estado de São Paulo não priorizaram em suas agendas administrativas tais questões, e em janeiro de 2014, com a queda no volume de chuvas e a redução constante nos reservatórios da região Sudeste, medidas efetivas e emergenciais tiveram que ser adotadas.

A Figura 9 permite a visualização da evolução do armazenamento do conjunto de reservatórios (Sistema Equivalente) do rio Paraíba do Sul, aferido pelo volume acumulado no mês em relação ao volume útil do reservatório.

Observa-se uma redução vigorosa dos volumes durante o ano 2014, passando de 48,5\% em janeiro para 2,6\% em dezembro. Essa redução não se restringiu apenas à bacia do rio Paraíba do Sul, se estendendo a todos os demais principais rios do estado de São Paulo, como foi observado anteriormente no estudo do comportamento dos reservatórios das usinas hidrelétricas localizadas na região Sudeste.

Nesse sentido, a partir de meados de 2014, a redução nos reservatórios do Sistema Cantareira e a necessidade de acordos entre os administradores da bacia do Paraíba do Sul, da bacia PCJ (rios Piracicaba, Capivari e Jundiaí) e do Sistema Cantareira e suas diversas interligações, desencadearam decisões e medidas de amplitude federal envolvendo variados atores, como: órgãos governamentais federais (ANA, Aneel, ONS), órgãos governamentais estaduais (Secretaria Estadual do Meio Ambiente; Secretaria Estadual de Saneamento e Recursos Hídricos; Secretaria Estadual de Energia; DAEE-Departamento de Água e Energia 
Elétrica), e representantes dos Comitês de Bacias (Ceivap; CPJ) e empresas privadas ou de economia mista como a Sabesp (Companhia de Saneamento Básico do Estado de São Paulo), a Cesp (Companhia Energética de São Paulo), Ligth $(\mathrm{RJ})$, que se utilizam de forma direta das águas dos rios em seus múltiplos usos.

Dentre as primeiras medidas adotadas, assinala-se a tentativa de regularização dos índices dos reservatórios e da vazão para os usos múltiplos das bacias que compõem o Sistema, com a ANA e o DAEE estabelecendo, por parte da Sabesp, a redução da vazão máxima de captação do Sistema Cantareira, responsável pelo abastecimento de aproximadamente nove milhões de pessoas na Região Metropolitana de São Paulo. Na sequência, a Sabesp reverteu a distribuição de 2,6 milhões de pessoas abastecidas pelo Sistema Cantareira para a captação do Sistema Guarapiranga e Sistema Ato Tietê.

Tais medidas, porém, não foram suficientes e os problemas se ampliaram ao longo dos meses seguintes.

Ainda em abril de 2014 o governo paulista manifestou a intenção de executar uma obra de transposição das águas do reservatório Jaguari para o Sistema Cantareira. $\mathrm{O}$ anúncio provocou uma intempestiva reação de ambos os governos do Rio de Janeiro e Minas Gerais. Como será analisado mais adiante, esse projeto foi retomado em fins de 2014 e início de 2015 , obtendo a aprovação da ANA, e a aquiescência dos governos mineiro e fluminense.

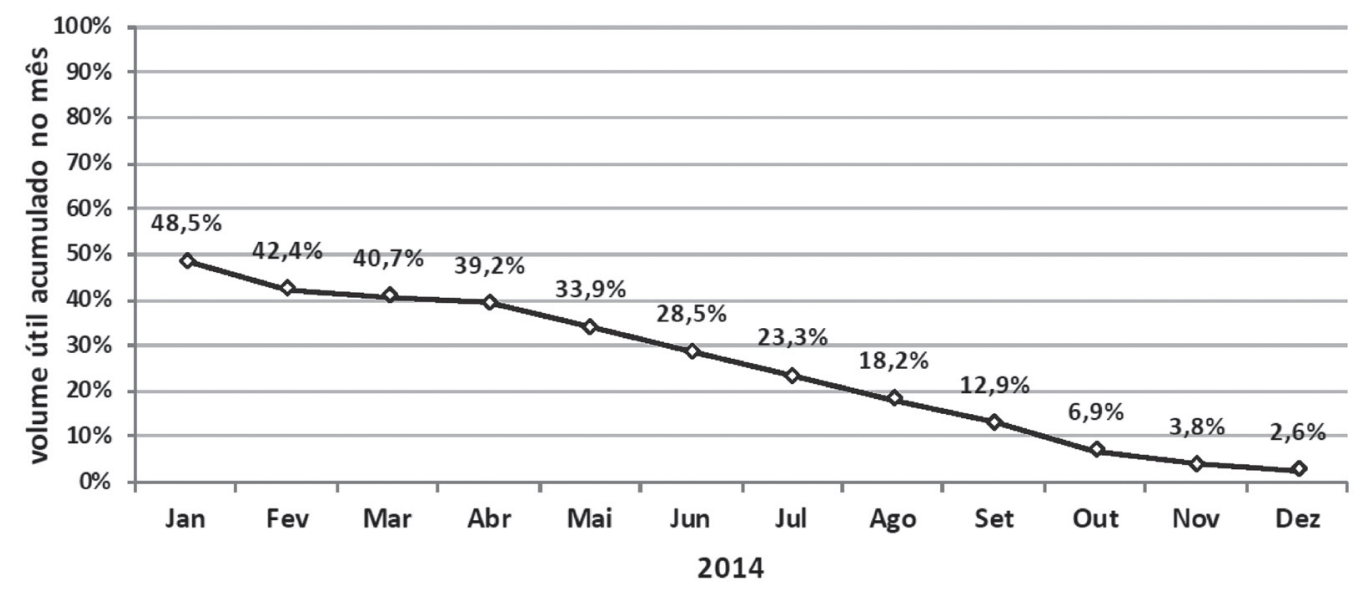

Fonte: ANA. Boletins de Monitoramento dos Reservatórios do Sistema Hidráulico do Rio Paraíba do Sul (março/2014 e janeiro/2015).

Figura 9 - Evolução do Armazenamento do Sistema Equivalente do Complexo Hidráulico Paraíba do Sul. 


\section{Características do Sistema Hidráulico do rio Paraíba do Sul}

De acordo com dados da ANA, o rio Paraíba Sul é considerado um rio federal, percorrendo em seu curso total uma extensão de $1.100 \mathrm{~km}$ e drena uma área total de aproximadamente $62.074 \mathrm{~km}^{2}$. Ao longo de seu percurso, o território da Bacia banha 184 municípios de três estados da região Sudeste do país, sendo: 39 munícipios de São Paulo, 59 munícipios do Rio de Janeiro e 88 munícipios de Minas Gerais.

O Sistema Hidráulico do rio Paraíba do Sul é um complexo conjunto de estruturas hidráulicas existentes nas bacias hidrográficas do Paraíba do Sul e do Guandu. Os principais reservatórios da bacia são Paraibuna, Santa Branca, Jaguari e Funil. A capacidade total desses reservatórios (Reservatório Equivalente) é de 7.294,7 milhões de metros cúbicos, dos quais 4.341,9 milhões de metros cúbicos estão dentro da faixa normal de operação (volume útil total). Desses, o reservatório de Paraibuna é o que possui a maior capacidade de armazenamento em termos de volume útil (61\%), seguido por Jaguari (18\%), Funil (14\%) e Santa Branca (7\%). Esses reservatórios estão localizados no estado de São Paulo, exceto o de Funil que se localiza no estado do Rio de Janeiro. A estação elevatória de Santa Cecília é a que efetiva a transposição entre as águas do Rio Paraíba do Sul para o Rio Guandu, cujas águas captadas são armazenadas no reservatório de Santana, onde se misturam às águas do rio Piraí.

A Figura 10 ilustra o Diagrama Esquemático do Sistema Hidráulico do rio Paraíba do Sul.

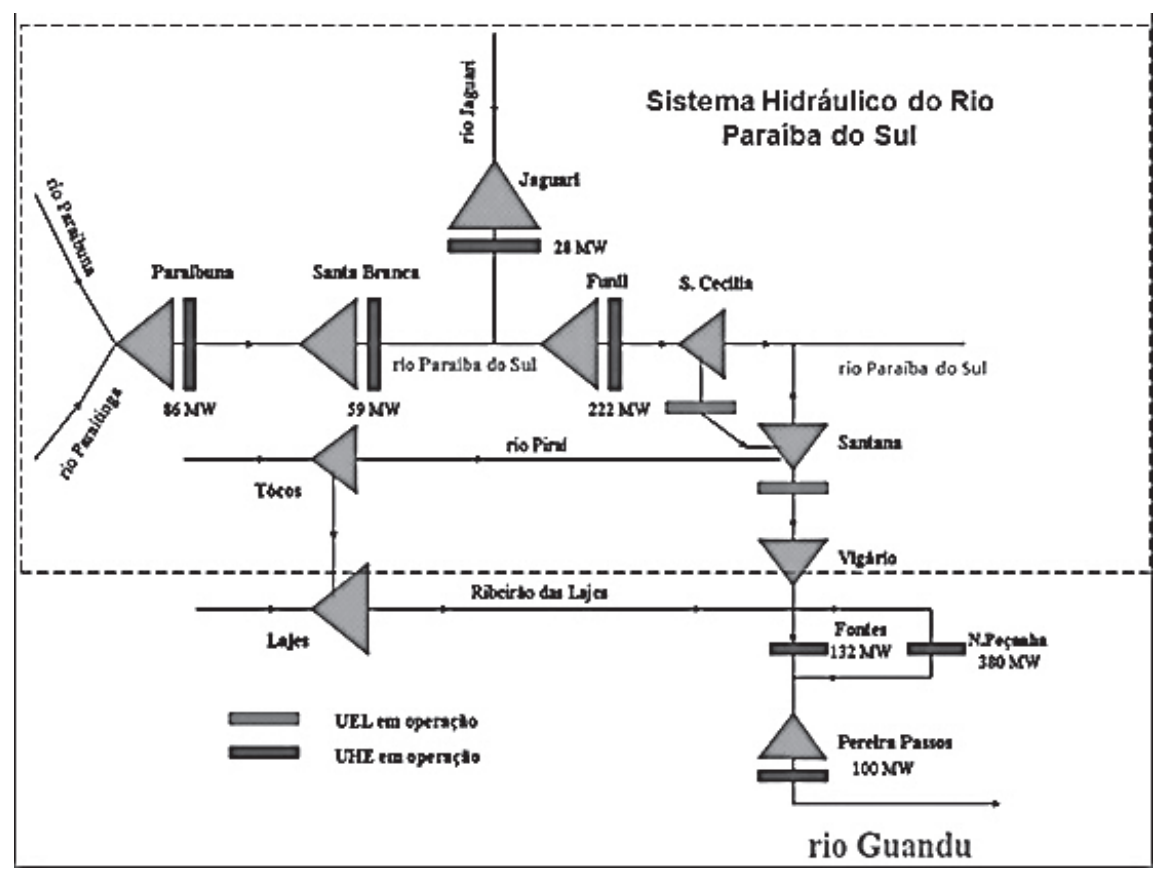

Fonte: ANA (2015b, p.17).

Figura 10 - Diagrama esquemático do Sistema Hidráulico do rio Paraíba do Sul. 
Mas foi na segunda semana do mês de agosto de 2014, que a utilização da água na cabeceira do rio Paraíba do Sul se tornou objeto de uma intensa controvérsia envolvendo os estados de São Paulo, Rio de Janeiro e Minas Gerais. O foco do conflito se evidenciou na disputa pelo destino de $20 \mathrm{~m}^{3} / \mathrm{s}$ do reservatório Jaguari - para a geração de energia elétrica ou para o abastecimento humano.

A gestão do reservatório Jaguari cabe à Companhia Energética de São Paulo (Cesp), pelo ato de outorga obtido pelo Decreto n.66.593/1970, que inclui a geração de energia elétrica com capacidade instalada total de 27,6 MW.

É importante destacar que a outorga que libera ou regula um ou outro uso múltiplo das águas em uma determinada bacia é estabelecida pela ANA e em sua determinação se atribui a garantia de vazão mínima para o requisitante. No entanto, em período de crise cabe a ANA, por meio de estudos ou solicitações, determinar a diminuição ou não da vazão a ser liberada por este ou aquele reservatório, na tentativa de equilibrar a vazão média dos rios que compõem as bacias e garantir minimamente os usos múltiplos.

Em 6 de agosto de 2014, com a justificativa de priorizar o abastecimento populacional, o governo do estado de São Paulo e a Cesp decidiram liberar no reservatório Jaguari, no Vale do Paraíba paulista, apenas $10 \mathrm{mil} \mathrm{m}^{3}$ de água por segundo, um terço do volume de água exigido para o rio Paraíba do Sul, que é responsável por abastecer cerca de 15 milhões de pessoas, a maioria no estado do Rio de Janeiro. Tal decisão descumpriu a ordem de despacho da ONS que determina ser de $30 \mathrm{mil} \mathrm{m}^{3}$ por segundo a vazão mínima a ser destinada ao Paraíba do Sul como forma de garantia do abastecimento humano e de energia da região.

Dos 52 municípios banhados pelo rio Paraíba do Sul, ou seus reservatórios formadores (Paraibuna e Paraitinga), 28 captam água do rio Paraíba do Sul para abastecimento público (ANA, 2015b, p.19), conforme evidenciam os dados apresentados na Tabela 7.

Muito embora os dados da Tabela 7 estejam desatualizados, uma vez que as informações da população abastecida se refiram a 2005, o total da população envolvida, da ordem de 2.227.872 habitantes, confere uma medida da importância do rio Paraíba do Sul para o abastecimento humano.

Por sua vez, a capacidade instalada das sete usinas hidrelétricas localizadas ao longo do rio Paraíba do Sul, é de 1.007 MW, sendo 173 MW no estado de São Paulo (Jaguari, Paraibuna, Santa Branca) e 834 MW no estado do Rio de Janeiro (Funil, Fontes, Nilo Peçanha, Pereira Passos).

O governo do estado de São Paulo, ao decidir reduzir a vazão a jusante do reservatório Jaguari, comprometeu tanto o abastecimento da população dos 28 municípios referenciados na Tabela 7 , sendo 12 paulistas, como a geração de energia elétrica nas quatro usinas hidrelétricas localizadas no estado do Rio de Janeiro. Particularmente, a Estação Elevatória de Santa Cecília, que deriva a água para o Sistema Guandu em conjunto com a UEL Santana, foi a mais prejudicada, afetando tanto a geração de energia elétrica como o abastecimento da Região Metropolitana do Rio de Janeiro. 
Tabela 7 - Relação dos municípios e população abastecida pelo rio Paraíba do Sul

\begin{tabular}{|c|c|c|}
\hline Município & $\begin{array}{l}\text { População abastecida pelo } \\
\text { rio Paraíba do Sul (hab) }\end{array}$ & $\begin{array}{c}\text { Demanda média no rio } \\
\text { Paraíba do Sul (L/s) }\end{array}$ \\
\hline Aparecida/SP & 34.498 & 92 \\
\hline Caçapava/SP & 7.251 & 4 \\
\hline Guararema/SP & 22.240 & 75 \\
\hline Jacareí/SP & 170.803 & 517 \\
\hline Natividade da Serra/SP & 2.788 & 9 \\
\hline Paraibuna/SP & 5.131 & 12 \\
\hline Pindamonhangaba/SP & 141.708 & 192 \\
\hline Redenção da Serra/SP & 1.881 & 3 \\
\hline Santa Branca/SP & 12.140 & 31 \\
\hline São José dos Campos/SP & 469.000 & 1.578 \\
\hline Taubaté/SP & 174.510 & 521 \\
\hline Tremembé/SP & 16.251 & 32 \\
\hline Barra do Piraí/RJ & 85.818 & 254 \\
\hline Barra Mansa/RJ & 162.748 & 472 \\
\hline Cambuci/SP & 6.433 & 29 \\
\hline Campos dos Goitacazes/RJ & 350.769 & 1.110 \\
\hline Itaocara/RJ & 11.463 & 42 \\
\hline Paraíba do Sul/RJ & 34.305 & 91 \\
\hline Pinheiral/RJ & 18.948 & 53 \\
\hline Porto Real/RJ & 13.655 & 42 \\
\hline Quatis/RJ & 9.501 & 27 \\
\hline Resende/RJ & 93.671 & 304 \\
\hline São Fidélis/RJ & 24.590 & 79 \\
\hline São joão da Barra/RJ & 10.215 & 36 \\
\hline Sapucaia/RJ & 4.659 & 33 \\
\hline Três Rios/RJ & 68.158 & 206 \\
\hline Vassouras/RJ & 19.154 & 58 \\
\hline Volta Redonda/RJ & 255.584 & 737 \\
\hline
\end{tabular}

Fonte: ANA. Atlas Brasil de abastecimento urbano de água, 2005. 
Dessa forma, constituiu-se o impasse. No dia 12 de agosto de 2014 a Aneel notificou oficialmente a Cesp para que a companhia aumentasse a quantidade de água do reservatório Jaguari para o rio Paraíba do Sul. A penalidade pelo não atendimento à ordem que vinha do ONS poderia ser uma advertência, ou uma multa no valor de até $2 \%$ do faturamento anual até a retirada da concessão da usina. Por sua vez, a ANA afirmou, em nota no mesmo dia, que "não recebeu nenhuma justificativa dos órgãos gestores estaduais de São Paulo para alterar a operação do reservatório Jaguari". Ainda, o órgão solicitou "estudos técnicos e jurídicos" que embasaram a decisão da Cesp de liberar apenas $10 \mathrm{~m}^{3} / \mathrm{s}$, em vez dos $30 \mathrm{~m}^{3} / \mathrm{s}$ pedidos, e finalizou a nota indicando que a medida da companhia paulista "não foi precedida de nenhum comunicado formal às instituições ou à sociedade" (cf. FSP, 13.8.2014, p.Cl).

Segundo vários órgãos da imprensa nacional, que passaram a definir o conflito com o termo "Guerra da Água", o impasse revelava uma disputa entre, de um lado, a Cesp e o DAEE, ambos órgãos do estado de São Paulo, e do outro lado, os órgãos federais ONS, Aneel e ANA.

No dia 14 de agosto, a Cesp, por determinação do governo paulista, resolveu aumentar a liberação de água de outra represa no rio Paraíba do Sul, a de Paraibuna, que passou de $63 \mathrm{~m}^{3} / \mathrm{s}$ para $80 \mathrm{~m}^{3} / \mathrm{s}$, compensando parcialmente a redução da represa Jaguari.

Por fim, no dia 18 de agosto, um acordo colocou um término na disputa pela água da bacia do rio Paraíba do Sul. A reunião que definiu os termos do acordo contou com a participação da ministra do Meio Ambiente, Izabella Teixeira; o diretor-presidente da ANA, Vicente Andreu; o secretário do Meio Ambiente do Rio de Janeiro, Carlos Portinho; o secretário de Saneamento e Recursos Hídricos de São Paulo, Mauro Arce; o secretário de Energia de São Paulo, Marco Antonio Moriz; o secretário-adjunto de Meio Ambiente do Minas Gerais e presidente do Comitê da Bacia Hidrográfica do Paraíba do Sul, Danilo Vieira Júnior; o diretor geral do ONS, Hermes Chipp; a presidente do Instituto do Meio Ambiente do Rio de Janeiro (Inea), Isaura Frega e a diretora-geral do Instituto Mineiro das Águas (Igam), Marília Melo.

Conforme o acordo, os governos paulista e fluminense passaram a realizar uma adequação das vazões - saídas de água - das represas existentes ao longo dos rios Jaguari e Paraíba do Sul, para evitar que elas percam volume rapidamente, em virtude da crise de abastecimento que atinge São Paulo desde o início do ano.

Pelo compromisso, a Cesp elevou a vazão da represa do rio Jaguari afluente do Paraíba do Sul -, dos atuais $10 \mathrm{~m}^{3} / \mathrm{s}$, para $43 \mathrm{~m}^{3} / \mathrm{s}$. No reservatório de Paraibuna, no trecho do rio Paraíba do Sul que fica em São Paulo, a vazão foi reduzida de $80 \mathrm{~m}^{3} / \mathrm{s}$ para $47 \mathrm{~m}^{3} / \mathrm{s}$. Por seu turno, o governo fluminense tomou medidas para se adequar à redução da vazão afluente na barragem de Santa Cecília, de $190 \mathrm{~m}^{3} / \mathrm{s}$ para $160 \mathrm{~m}^{3} / \mathrm{s}$. 
A despeito do acordo, cabe assinalar que em 3 de outubro de 2014, a Agência Nacional de Energia Elétrica (Aneel) multou a Companhia Energética de São Paulo (Cesp) em R \$ 5,385 milhões por descumprir ordem para produção de energia na hidrelétrica de Jaguari. Na oportunidade, a empresa informou que iria recorrer da decisão. Não há registros da situação final a que a penalidade financeira alcançou (OESP, 3.10.2014).

A disputa, no entanto, parece querer se estender com o projeto de transposição de água do reservatório Jaguari para o Sistema Cantareira, proposto pelo governo paulista em abril de 2014. Um primeiro acordo foi alcançado em 16 de janeiro de 2015, com a aprovação do projeto pela ANA. Com um custo de R\$ 830 milhões, a obra consiste na interligação por meio de uma rede de tubulações e bombas, da represa Jaguari no rio Paraíba do Sul, com a represa Atibainha, no Sistema Cantareira. Calcula-se que tal ligação levará, em média, 5.130 a 8.500 litros de água por segundo do rio Paraíba do Sul para o Sistema Cantareira.

Vale assinalar que, a respeito do projeto de transposição concebido em 2010, um estudo elaborado por pesquisadores do Laboratório de Hidrologia e Estudos de Meio Ambiente (Coppetec) da UFRJ, contratados pelo Instituto Estadual do Ambiente (Inea/RJ), e que foi apresentado ao governo fluminense em 2013, indicava que a obra de transposição diminuirá em 4,2\% capacidade de geração de energia dos reservatórios da principal bacia hidrográfica do estado. Essa queda de capacidade, provocada pela menor vazão do rio, teria um impacto de R 20 milhões por ano para as geradoras e distribuidoras de energia.

Agora ignorado pelo governo estadual fluminense, o relatório alertava que a alta dos custos pode ser ainda maior pelo possível acionamento de termelétricas para suprir a demanda. Além disso, não foi considerado o impacto da diminuição da vazão do Paraíba do Sul sobre o Complexo Hidrelétrico de Lajes, no Rio, operado pela Light. (cf. Valor Econômico, 19.1.2015).

O relato dos fatos possibilita constatar a ausência de mecanismos institucionais que permitam superar o confronto de interesses de âmbito estadual, entre diferentes estados.

A despeito do que afirmam diversos gestores de órgãos federais, entre os quais o secretário-executivo do Ministério de Minas e Energia, Márcio Zimmermann, para quem "É errado dizer que se trata de um conflito entre energia elétrica e água. Não é" (cf. OESP, 16.8.2014), o conflito entre energia elétrica e água é evidente.

Tal posição apresentada por Zimmermann exprime a estratégia da negação, mesmo ante os fatos. Uma administração ineficiente e inapta na condução dos conflitos, opta por não reconhecê-los.

Ainda segundo Zimmermann, a respeito da posição adotada pelo governo de São Paulo ante a determinação do ONS, "Pela primeira vez no Brasil, alguém se rebela ao comando do ONS. Se todo mundo resolver fazer isso, o sistema vira o caos", ressaltou. "A Cesp e o Estado de São Paulo quebraram a cadeia de 
comando. Isso é algo muito grave e temos o dever de acompanhar" (cf. OESP, 16.8.2014).

Dessa feita, a referência a um suposto "dever" de uma companhia concessionária estadual das atividades de geração de energia elétrica, de obediência às determinações de um órgão federal, evidencia o caráter impositivo com que é conduzida a operação do Sistema Elétrico Brasileiro.

Evidentemente, não se retira aqui a importância de haver um órgão de gestão centralizada para garantir a geração de energia a nível nacional. O Sistema Elétrico Brasileiro se caracteriza por ser extremamente extenso, o que não deixa de ser favorável, em razão do esforço histórico de interligar sistemas e promover $\mathrm{o}$ intercâmbio inter-regional. O ONS tem a atribuição de monitorar o sistema de despacho de carga (geração e transmissão) de acordo com a demanda. A tecnologia atual possibilita que o ONS execute essa tarefa em tempo real, podendo antecipar eventuais desequilíbrios entre a oferta e a demanda. ${ }^{3}$

O despacho de carga é realizado pelo critério econômico, colocando no sistema, que é interligado, isto é, possibilitando intercâmbios de energia entre as várias regiões do país, a energia elétrica de menor custo de produção, acrescentando na medida das necessidades, e de forma sucessiva, custos maiores.

O sistema hidrotérmico é utilizado de forma a complementar a oferta com a termoeletricidade de fontes fósseis (derivados de petróleo, carvão mineral, gás natural) ou termonuclear, quando o sistema hidrelétrico é insuficiente.

Existiam, entretanto, outras fontes opcionais para complementar a hidreletricidade que não foram contempladas durante a crise hídrica.

Por exemplo, uma delas seria o aproveitamento da biomassa a partir do bagaço da cana de açúcar, em regime de cogeração. O país possui um enorme potencial de oito mil MW que poderiam ser colocados no sistema. Hoje, o sistema interligado absorve em torno de 1,2 mil MW; portanto, há uma grande quantidade que poderia ser incorporada. De forma intermitente, é verdade, mas vamos lembrar que a usina hidrelétrica também é uma forma intermitente de gerar energia. Não garante disponibilidade de energia o tempo todo. O bagaço, durante o período da colheita da cana, seja para a produção do etanol ou de açúcar, deveria ser aproveitado pelo país, em função de seu baixo custo e da possibilidade de complementação no período de safra. E o período da safra coincide com o período da baixa pluviosidade nos reservatórios das usinas hidrelétricas localizadas na região Sudeste.

O problema para que se alcance uma efetiva complementação dessa energia da biomassa reside numa imposição da Agência Nacional de Energia Elétrica (Aneel), de que cabe à usina sucroalcooleira levar energia elétrica do seu local até o sistema de transmissão e distribuição. Trata-se de um investimento relativamente pequeno, mas que os usineiros da cana não querem se comprometer a fazer, e não encontram nos bancos públicos apoio para executar. É um potencial que poderia ser utilizado e está enterrado. 
Haveria condições de superar o problema com a participação do BNDES no aporte dos recursos financeiros necessários para possibilitar a construção da linha de transmissão de energia entre a usina sucoalcooleira e a rede de distribuição de energia. Esses recursos poderiam também possibilitar o aumento da capacidade de cogeração, através de caldeiras de maior pressão, o que aumentaria a capacidade de geração de excedente de energia elétrica para o sistema.

Outra opção seria a utilização da energia eólica em complementação com a hidroeletricidade. Na região Nordeste, onde o potencial eólico alcança 75.000 MW (Cresesb/Cepel, 2001) o regime de ventos é complementar ao período de estiagem hídrica. Ou seja, a intensidade e frequência dos ventos são maiores nos períodos em que o nível dos reservatórios das usinas hidrelétricas está mais baixo.

Mesmo considerando que o parque eólico instalado no Brasil teve um vigoroso crescimento no período 2013-2014, com a capacidade de geração passando de 2.211 MW para 4.953 MW, a participação da energia eólica na oferta de eletricidade ainda é de 3,6\% (MME/SSE, 2015). Há que assinalar que muitas das usinas eólicas que foram construídas não puderam despachar energia por ausência de linhas de transmissão, o que novamente evidencia problemas de gestão no Sistema Elétrico Brasileiro.

\section{Considerações finais}

O uso múltiplo das águas em reservatórios de usinas hidrelétricas é ainda um assunto a ser normatizado. A ausência de mecanismos institucionais que disciplinem de forma adequada o conflito de interesses com a geração de energia elétrica torna a matéria recorrente, com uma frequente sucessão de impasses de difícil superação.

A ideia da introdução de regras nas outorgas e nos contratos de concessão definidos entre a União e as companhias de geração de energia elétrica, no sentido de incorporarem os usos múltiplos das águas nas condições de operação dos reservatórios das usinas hidrelétrica, comparece como passo necessário de definição. Neste o processo, o envolvimento das populações através dos Comitês de Bacias deve ser dinamizado.

A recente crise hídrica no Sudeste foi reveladora das insuficiências e da necessidade de se abandonar o caráter prioritário com que a geração de energia foi historicamente se constituindo, como demonstrado neste estudo.

A judicialização dos conflitos, como também foi demonstrado no presente estudo, não parece ser o melhor caminho para que o equilíbrio entre a geração de energia e o uso múltiplo seja alcançado. Sem dúvida, o necessário equilíbrio, formulado em bases técnicas que fundamentem condições adequadas de gestão dos reservatórios hidrelétricos, e desvinculadas de contextos políticos, deve ser alcançado, para benefício econômico, social e ambiental das populações envolvidas. 
Notas

1 Dados disponíveis em: <http://www.ons.org.br/historico/percentual_volume_util. aspx>.

2 Sobre os erros anteriores na política energética ver: Entrevista ao Instituto Humanitas Unisinos "A política energética e a MP 579: um debate político e corporativista" em 6.12.2012. Disponível em: <http://www.ihu.unisinos.br/entrevistas/516209-mp-579-um-debate-politico-e-corporativista-entrevista-especial-com-celio-bermann>. Entrevista ao Correio da Cidadania "População pagará pela desastrosa gestão PT-PMDB no setor elétrico" em 23.2.2015. Disponível em: <http://www.correiocidadania.com.br/index.php?option=com_content\&view=article\&id=10525: manchete 210215\&catid=72:imagens-rolantes $>$.

3 Foi o caso da interrupção de energia elétrica ocorrida na tarde do dia 19 de janeiro de 2014, quando o ONS determinou a empresas concessionárias de distribuição de energia de dez estados o corte no fornecimento para "alívio de carga do sistema".

\section{Referências}

AGÊNCIA PÚBLICA. Ilha Solteira pede água, 10.03.2015. Disponível em: <http:// apublica.org/2015/03/ilha-solteira-pede-agua/>. Acesso em: 5 jun. 2015.

ANA. Atlas Brasil de Abastecimento Urbano de Água, 2005.

ANA. Boletins de Monitoramento dos Reservatórios do Sistema Hidráulico do Rio Paraiba do Sul. Brasília, v.9, mar. 2014 e v.10, jan. 2015a.

ANA. Conjuntura dos Recursos Hidricos no Brasil-Informe 2014. Brasília, 20.3.2015b.

ANEEL. Boletim Informativo da Geração, 2015.

BRASIL. Decreto n.24.643 (Código das Águas). Governo Provisório da República dos Estados Unidos do Brasil. Rio de Janeiro, 10.7.1934. Disponível em: <https://www. planalto.gov.br/ccivil_03/decreto/d24643.htm>. Acesso em: 8 jun. 2015.

BRASIL. Lei $n^{\circ} 9.433$ (Politica Nacional de Recursos Hidricos). Presidência da República Federativa do Brasil. Brasília, 8.1.1997. Disponível em: <http://www.planalto.gov. br/ccivil_03/LeIs/L9433.htm>. Acesso em: 8 jun. 2015.

CRESESB/CEPEL. Atlas do Potencial É́lico Brasileiro. Rio de Janeiro, 2001.

ESP. Agência multa Cesp por vazão menor de rio, 03.10.2014. Disponível em: <http:// sao-paulo.estadao.com.br/noticias/geral,agencia-multa-cesp-por-vazao-menor-de-rio,1570546>. Acesso em: 15 jun. 2015.

ESP. Governo federal acusa SP de prejudicar o abastecimento, 16.8.2014. Disponível em: <http://www.estadao.com.br/noticias/geral,governo-federal-acusa-sp-de-prejudicar-abastecimento,1544873>. Acesso em: 17 jun. 2015.

FSP. Agência federal manda SP liberar mais água, 13.8.2014, p. C1. Disponível em: <http://acervo.folha.com.br/fsp/2014/08/13/15/>. Acesso em: 10 jun. 2015.

LOPES, J. E. G.; SANTOS, R. C. P. Capacidade de Reservatórios. Departamento de Engenharia Hidráulica e Sanitária - Escola Politécnica da USP. São Paulo, julho. 2002.

MME/SSE. Boletim Mensal de Monitoramento do Sistema Elétrico Brasileiro, dez. 2014. 
ONS. Volume Útil dos Principais Reservatórios, 2015.

VALOR ECONÔMICO. ANA autoriza interligação do rio Paraíba do Sul, 19. 1.2015. Disponível em: <http://www.valor.com.br/empresas/3865394/ana-autoriza-interligacao-do-rio-paraiba-do-sul-com-cantareira>. Acesso em: 18 jun. 2015.

RESUMO - O artigo tem como foco o conflito existente entre a geração de energia elétrica e o uso múltiplo das águas no país. Apesar da existência de uma legislação que define, em situação de escassez, o uso prioritário para o consumo humano e a dessedentação dos animais, a recente crise hídrica revela uma série de conflitos envolvendo o Sistema Elétrico Brasileiro, suas empresas e seus órgãos de gestão, e os demais usos como a irrigação, a piscicultura, a navegabilidade para transporte e lazer. Com base nos dados referentes ao comportamento dos volumes úteis de alguns dos principais reservatórios de usinas hidrelétricas localizadas na região Sudeste, é analisada a crise na disponibilidade de energia elétrica no período 2013-2014 e suas consequências. Em particular, é analisado o conflito pelo uso da água no rio Paraíba do Sul ocorrido em agosto de 2014 .

PALAVRAS-CHAVE: Hidrelétricas, Geração de energia elétrica, Uso múltiplo das águas, Conflitos ambientais.

ABSTRACT - The article focuses on the conflict between the generation of electric power and the multiple use of water in Brazil. Despite the existence of legislation that defines, in situations of scarcity, the priority use for human consumption and watering of animals, the recent water crisis reveals a series of conflicts involving the Brazilian Electric System, their companies and their management, and other uses such as irrigation, fish farming, transport and leisure activities. On the basis of the data relating to the behaviour of useful volumes of some of the main reservoirs of hydroelectric plants located in the Southeast, is considered the crisis in the availability of electricity in 2013-2014 period and its consequences. In particular, it is analyzed the conflict by the use of water in the Paraíba do Sul River occurred in August 2014.

KEYWORDS: Hydroelectric power plants, Electric power generation, Multiple use of water, Environmental conflicts.

Jucilene Galvão é doutoranda em Energia pelo Programa de Pós-Graduação em Energia da Universidade de São Paulo (PPGE/USP). @ - jucigalvao@yahoo.com.br

Célio Bermann é professor associado 2 do Instituto de Energia e Ambiente da Universidade de São Paulo (IEE/USP). Coordenador do Programa de Pós-Graduação em Energia da USP. Membro do Grupo de Pesquisa "Meio Ambiente e Sociedade" do IEA/ USP. Bolsista de Produtividade do CNPq. @ - cbermann@iee.usp.br

Recebido em 24.6.2015 e aceito em 6.7.2015.

I, II Instituto de Energia e Ambiente, Universidade de São Paulo. São Paulo/SP, Brasil. 